\title{
Advanced Primary Pulmonary
Carcinosarcoma: A Case Report and Review of the Literature
}

\section{İlerlemiş Primer Pulmoner Karsinosarkom: Olgu sunumu ve Literatürün Gözden Geçirilmesi}

Iliass Elalami', Rachid Tanz', Mohamed Amine Azami², Mohamed Allaoui', Hassan Errihani ${ }^{3}$, Mohamed Ichou'

\section{Abstract}

Pulmonary carcinosarcoma (PCS) is a rare tumor, that comprises approximately $0.2 \%$ to $0.4 \%$ of all pulmonary neoplasms. PCS was defined in the World Health Organization classification as "poorly differentiated non-small cell lung carcinomas containing a sarcoma-like element or sarcomatous component". Presently, described is case of a 46-year-old male who presented with advanced primary PCS.

Key words: Pulmonary carcinosarcoma, sarcomatoid carcinoma, chemotherapy.

\section{Özet}

Pulmoner karsinosarkom nadir bir tümör olup tüm pulmoner maligniteler içerisinde yaklaşı \%0,2 ile $\% 0,4$ arasında görülmektedir. Pulmoner karsinosarkom Dünya Sağlık Örgütü sınıflamasında "sarkom benzeri element veya sarkomatöz komponent içeren az differansiye küçük hücreli dışı akciğer kanseri" olarak tanımlanmıştır. Illeri evre primer pulmoner karsinosarkom saptanan 46 yaşındaki erkek olguyu sunuyoruz.

Anahtar Sözcükler: Pulmoner karsinosarkom, sarkomatoid karsinoma, kemoterapi.
Carcinosarcoma (CSA) of the lung is a rare malignant tumor. It was first defined by Kika et al. (1) in 1908 as poorly differentiated non-small cell carcinoma containing a component with sarcoma or sarcoma-like features. It is estimated to account for only $0.2 \%$ to $0.4 \%$ of all pulmonary neoplasms (2). There are strong associations with smoking and asbestosis. Clinical characteristics, preoperative diagnostic methods, and prognostic factors are still not completely understood (3). Prognosis is poor; 2 -year survival after surgical resection is not greater than $10 \%$ (4). Described is a new case of patient with advanced primary PCS.
'Department of Medical Oncology, Military Hospital Med V Faculty of Medicine, Mohamed V University, Rabat, Morocco

${ }^{2}$ Department of Pathology, Military Hospital Med V Faculty of Medicine, Mohamed V University, Rabat, Morocco

${ }^{3}$ Department of Medical Oncology, National Institute of Oncology, Rabat, Morocco
'Mohamed V Üniversitesi, Tıp Fakültesi Askeri Hastanesi, Tıbbi Onkoloji Anabilim Dalı, Rabat, Fas

${ }^{2}$ Mohamed V Üniversitesi, Tıp Fakültesi Askeri Hastanesi, Patoloji Anabilim Dalı, Rabat, Fas

${ }^{3}$ Ulusal Onkoloji Enstitüsü, Tıbbi Onkoloji Anabilim Dalı, Rabat, Fas

Submitted (Başvuru tarihi): 04.07.2016 Accepted (Kabul tarihi): 15.11.2016

Correspondence (iletişim): Rachid Tanz, Department of Medical Oncology, Military Hospital Med V Faculty of Medicine, Mohamed $\checkmark$ University, Rabat, Morocco

e-mail: tanz.rachid@gmail.com 


\section{CASE}

A 46-year-old man with history of 25 years of smoking complained of chest pain, cough, hemoptysis, and weight loss. Physical examination was normal. Chest X-ray revealed heterogeneous mass in the right pulmonary lobe. Chest computerized tomography (CT) revealed large mass measuring $11 \times 10 \mathrm{~cm}$ extending to the pleural and thoracic spine (Figure 1).

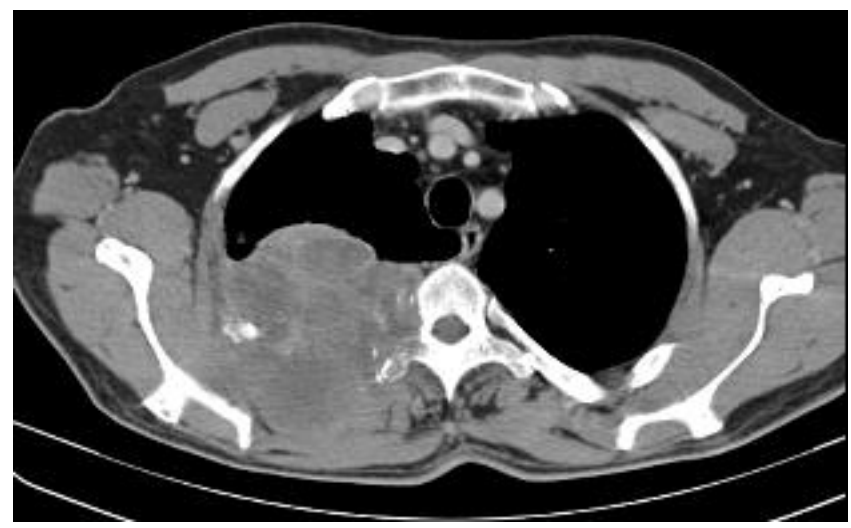

Figure 1: Chest computed tomography scan indicating right pulmonary mass

Transparietal biopsy was performed. Microscopic examination of biopsy specimen revealed infiltrating neoplasm with biphasic pattern (epithelial and sarcomatous components). Epithelial component was made up of massive cells of undifferentiated carcinoma with high cytonuclear atypia. Sarcomatous component was made up of spindle cells with hyperchromatic nuclei, arranged in bundles. Immunohistochemical study revealed that epithelial component expressed cytokeratin antigen (AE1/AE3), while sarcomatous component expressed vimentin antigen and thyroid transcription factor 1 (Figure 2). According to these findings, final diagnosis of PCS was made.

CT of the head was normal; bone scan revealed multiple bone metastases. Pathological stage was therefore stage IV. Surgery and radiotherapy were challenged and palliative chemotherapy was recommended with docetaxel (75 $\left.\mathrm{mg} / \mathrm{m}^{2}\right)$ and cisplatin $\left(80 \mathrm{mg} / \mathrm{m}^{2}\right)$ for 3 cycles. The patient died within 4-month follow-up period.

\section{DISCUSSION}

PCS is a rare tumor that comprises approximately $0.2 \%$ to $0.4 \%$ of all pulmonary neoplasms (2). The literature reports 4 to 7.25 -fold male (5). Mean age at diagnosis is between 65 and 75 years. Some cases have been reported related to asbestos exposure. In a study conducted by Fishback (3), $3 \%$ of patients with sarcomatoid carcinoma (SC) were exposed to asbestos. Thus, there could be direct mechanism between toxicity of asbestos and emergence of sarcomatoid component $(6,7)$

Clinical presentation of central localization-type involves cough, dyspnea, and hemoptysis, like other endobronchial tumors. The second type of PCS, peripheral, solid, parenchymal-type, often presents as large mass. These tumors are asymptomatic in the early stage, during which time they may involve adjacent organs or structures, such as the mediastinum, pleura, and thoracic wall (8). In our patient, dyspnea and cough were first symptoms to appear, followed by rapid deterioration of physical condition.

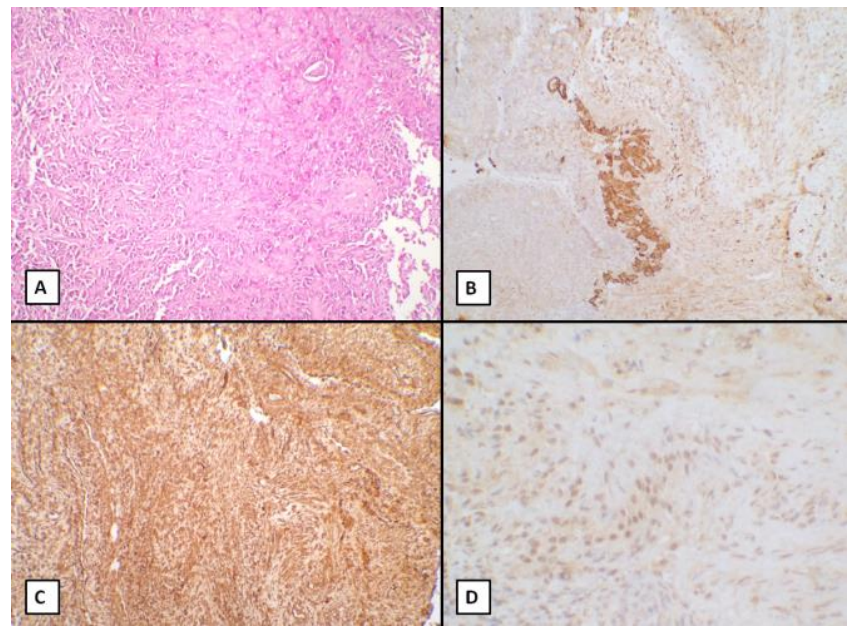

Figure 2a, b, $c$ and $d$ : A) Pulmonary parenchyma revealing infiltration of biphasic malignant tumor (hematoxylin and eosin; magnification x200); B) Pancytokeratin expression in the epithelial component; C) Vimentin immunohistochemical stain positive in the mesenchymal component; D) Epithelial pattern expressing thyroid transcription factor

Radiologically, SC is usually a single lesion with large diameter (from 40 to $180 \mathrm{~mm}$ ) and central or peripheral location in the upper lobes. Tumor is usually locally advanced at time of diagnosis, with large proportion of pleural invasion, either visceral or parietal (40-70\% of cases) $(7,9)$. Present patient had large tumors (118 and $95 \mathrm{~mm}$, respectively) with parietal invasion.

PCS is defined in the World Health Organization classification as "poorly differentiated non-small cell lung carcinoma (NSCLC) containing sarcoma-like element (malignant spindle or giant cells) or sarcomatous component (9). Five types of carcinoma have been defined, based on specific histological criteria: giant cell carcinoma, pleomorphic carcinoma, CSA, spindle cell carcinoma, and pulmonary blastoma. Although CSA is generally difficult to diagnose preoperatively due to mixed composition of both epithelial and sarcomatous components, several reports have described preoperative diagnosis at approximate rate of $0 \%$ to $12 \%(7,10)$. Macroscopically, CSA is 
usually gray-white in color, with hemorrhagic and/or necrotic areas $(11,12)$.

CSA is a malignant tumor that consists of mixture of NSCLC (typically squamous cell carcinoma in [40-70\%] or adenocarcinoma) and sarcoma-containing heterologous elements, such as rhabdomyosarcoma, chondrosarcoma, and osteosarcoma.

Immunohistochemistry can prove epithelial nature of proliferation of predominantly fusiform or giant cells based on positivity of pancytokeratins. Pancytokeratin AE1/AE3 appears to be most sensitive in recognizing epithelial component (13). Other epithelial markers, such as epithelial membrane antigen, CAM5.2 (including pancytokeratin CK 18) or p63/p40, may help in identification of epithelial component. However, vimentin is not a specific marker of mesenchymal tumor because many carcinomas express and especially bronchopulmonary adenocarcinoma. Some markers, such as actin, desmin, myoglobin, and S100 protein, also help to better characterize sarcomatoid contingent of CSA (14).

CSA is a clonal tumor developing via sarcomatoid change in a carcinoma. TP53 mutations are often present in CSA, whereas KRAS mutations occur less frequently, and EGFR mutations are very uncommon (15).

Programmed death-1 (PD-1) is a co-inhibitory inducible receptor present on T-cells and macrophages. Tumor cells with increased programmed death ligand-1 (PD-L1) are believed to escape immunity through activation of PD-1/PD-L1 pathway and suppression of effector immune responses. Recent strategies targeting PD-1/PD-L1 axis have shown promising results in patients with several tumor types, including lung carcinomas. Expression of PD-L1 in 13 SCs from 2 large retrospective lung cancer cohorts showed that 9 of 13 (69.2\%) patients with SCs were positive for PD-L1, and level was higher than in conventional NSCLC. These results provide rationale for potential use of targeted immunotherapy in lung SC (16). For localized tumors, complete surgical removal of tumor with negative tumor margins constitutes desired treatment approach. In addition to surgical resection, radiation is well established and effective as standard therapy in combination with surgery. Even if the sarcoma is resected incompletely and resection margins show residual tumor on microscopy, rate of local recurrence can be reduced to about $15 \%$ with local radiation therapy (17). However, there is limited information on systemic treatment options, such as chemotherapy and radiotherapy, for metastatic disease $(18,19)$.
There are few reports discussing chemotherapy for CSA due to rarity of this entity. Two reports have demonstrated efficacy of doxorubicin-based chemotherapeutic regimen and combination of cisplatin and doxorubicin (19). Aggressive nature and poor differentiation of this tumor render treatment difficult and result in poor prognosis (20).

\section{ABBREVIATIONS}

PCS: Pulmonary carcinosarcoma; NSCLCs: non-small cell lung carcinomas; WHO: World Health Organization; CSA: Carcinosarcoma; CT: computerized tomography; TTF 1: thyroid transcription factor

\section{CONFLICTS OF INTEREST}

None declared.

\section{AUTHOR CONTRIBUTIONS}

Concept - I.E., R.T., M.A.A., M.A., H.E., M.I.; Planning and Design - I.E., R.T., M.A.A., M.A., H.E., M.I.; Supervision - I.E., R.T., M.A.A., M.A., H.E., M.I.; Funding -; Materials -; Data Collection and/or Processing -; Analysis and/or Interpretation -; Literature Review -; Writing -; Critical Review -

\section{YAZAR KATKILARI}

Fikir - I.E., R.T., M.A.A., M.A., H.E., M.I.; Tasarım ve Dizayn - I.E., R.T., M.A.A., M.A., H.E., M.I.; Denetleme I.E., R.T., M.A.A., M.A., H.E., M.I.; Kaynaklar -; Malzemeler -; Veri Toplama ve/veya İşleme -; Analiz ve/veya Yorum -; Literatür Taraması -; Yazıyı Yazan -; Eleştirel Inceleme -

\section{REFERENCES}

1. Kakos GS, Williams Jr TE, Assor D, Vasko JS. Pulmonary carcinosarcoma. Etiologic, therapeutic, and prognostic considerations. J Thorac Cardiovasc Surg 1971; $61: 777-83$.

2. Sato S, Koike T, Yamato Y, Yoshiya K, Motono N, Takeshige $M$, et al. A case of rapidly growing pulmonary carcinosarcoma. Int J Clin Oncol 2010; 15:319-24. [CrossRef]

3. Fishback NF, Travis WD, Moran CA, Guinee DG Jr, McCarthy WF, Koss MN. Pleomorphic (spindle/giant cell) carcinoma of the lung: a clinicopathologic correlation of 78 cases. Cancer 1994; 73:2936-45. [CrossRef] 
4. Martin LW, Correa AM, Ordonez NG, Roth JA, Swisher SG, Vaporciyan AA, et al. Sarcomatoid carcinoma of the lung: a predictor of poor prognosis. Ann Thorac Surg 2007; 84:973-80. [CrossRef]

5. Nakajima M1, Kasai T, Hashimoto H, Iwata $Y$, Manabe $H$. Sarcomatoid carcinoma of the lung: a clinicopathologic study of 37 cases. Cancer 1999; 86:608-16. [CrossRef]

6. Ishida T, Tateishi M, Kaneko S, Yano T, Mitsudomi T, Sugimachi $K$, et al. Carcinosarcoma and spindle cell carcinoma of the lung. Clinicopathologic and immunohistochemical studies. J Thorac Cardiovasc Surg 1990; 100:844-52.

7. Davis MP, Eagan RT, Weiland LH, Pairolero PC. Carcinosarcoma of the lung: Mayo Clinic experience and response to chemotherapy. Mayo Clin Proc 1984; 59:598603. [CrossRef]

8. Humphrey PAI, Scroggs MW, Roggli VL, Shelburne JD. Pulmonary carcinomas with a sarcomatoid element: an immunocytochemical and ultrastructural analysis. Hum Pathol 1988; 19:155-65. [CrossRef]

9. Travis WD, Brambilla E, Müller-Hermelink K, Harris C, Kleihues C, Sobin P. Pathology and genetics of tumors of the lung, pleura, thymus, and heart. World Health Organization Classification of Tumours. Lyon: IARC Press; 2004. p. 53-58. http://www.iarc.fr/en/publications/pdfsonline/pat-gen/bb10/BB10

10. Huwer $H$, Kalweit $G$, Straub U, Feindt P, Volkmer I, Gams E. Pulmonary carcinosarcoma: diagnostic problems and determinants of the prognosis. Eur J Cardiothorac Surg 1996; 10:403-7. [CrossRef]

11. Kim KI, Flint JD, Müller NL. Pulmonary carcinosarcoma: radiologic and pathologic findings in three patients. AJR Am J Roentgenol 1997; 169:691-4. [CrossRef]

12. Koss MN, Hochholzer L, Frommelt RA. Carcinosarcomas of the lung: a clinicopathologic study of 66 patients. Am J Surg Pathol 1999; 23:1514-26. [CrossRef]
13. Travis WD. Sarcomatoid neoplasms of the lung and pleura. Arch Pathol Lab Med 2010; 134:1645-58. [CrossRef]

14. Vieira $T$, Antoine $M$, Ruppert $A M$, Fallet $V$, Duruisseaux $M$, Giroux Leprieur $E$, et al. Blood vessel invasion is a major feature and a factor of poor prognosis in sarcomatoid carcinoma of the lung. Lung Cancer 2014; 85:276-81. [CrossRef]

15. Travis WD, Brambilla E, Nicholson AG, Yatabe $Y$, Austin $\mathrm{JH}$, Beasley MB, et al. The 2015 World Health Organization Classification of Lung Tumors: Impact of Genetic, Clinical and Radiologic Advances Since the 2004 Classification. J Thorac Oncol. 2015;10: 1243-60. [CrossRef]

16. Velcheti V, Rimm DL, Schalper KA. Sarcomatoid lung carcinomas show high levels of programmed death ligand-1 (PD-L1); J Thorac Oncol 2013; 8: 803-5. [CrossRef]

17. Braham E, Ben Rejeb H, Aouadi S, Kilani T, El Mezni F. Pulmonary carcinosarcoma with heterologous component: report of two cases with literature review. Ann Transl Med 2014; 2:41. [CrossRef]

18. Sugano T, Mori M, Namba Y, Uenami T, Kagami S, Yokota $S$. A case of sarcomatoid carcinoma of the lung successfully treated with carboplatin, paclitaxel and bevacizumab. Nihon Kokyuki Gakkai Zasshi 2011; 49:304-8

19. Langer F, Wintzer HO, Werner M, Weber C, Brümmendorf $\mathrm{TH}$, Bokemeyer $\mathrm{C}$. A case of pulmonary carcinosarcoma (squamous cell carcinoma and osteosarcoma) treated with cisplatin and doxorubicin. Anticancer Res 2006; 26:3893-7.

20. Pelosi G1, Sonzogni A, De Pas T, Galetta D, Veronesi G, Spaggiari L, et al., Pulmonary sarcomatoid carcinomas: a practical overview Int J Surg Pathol 2010; 18:103-20. [CrossRef] 